\title{
Review Article \\ Role of Atmospheric Aerosol Content on Atmospheric Corrosion of Metallic Materials
}

\author{
M. E. Emetere ${ }^{1 D},{ }^{1,2}$ S. A. Afolalu, ${ }^{1}$ L. M. Amusan, ${ }^{1}$ and A. Mamudu ${ }^{1}$ \\ ${ }^{1}$ Covenant University Canaanland, P.M.B. 1023, Ota, Nigeria \\ ${ }^{2}$ Department of Mechanical Engineering and Science, University of Johannesburg, APK, South Africa \\ Correspondence should be addressed to M. E. Emetere; moses.emetere@covenantuniversity.edu.ng
}

Received 20 October 2020; Revised 10 January 2021; Accepted 28 January 2021; Published 12 February 2021

Academic Editor: Ramazan Solmaz

Copyright (C) 2021 M. E. Emetere et al. This is an open access article distributed under the Creative Commons Attribution License, which permits unrestricted use, distribution, and reproduction in any medium, provided the original work is properly cited.

\begin{abstract}
Despite extensive work on improving atmospheric corrosion resistance in metals, i.e., steel and alloy, the corrosion rate on the metallic surface is higher at some localized geographical area of the globe. Despite the visible successes in recent coating technology in curbing environmental conditions, it is proposed that the recent increase of atmospheric bioaerosols has a significant role in the dissolution of corrosion-resistant coating over a metallic surface. In this review, the science of atmospheric corrosion on metallic materials was reviewed in the light of the chemical and physical composition of atmospheric bioaerosols and aerosols. It was observed that aside from general conditions (i.e., alloying element level, surface roughness, surface treatment, and microclimate), the bioaerosols content is essential for future research in corrosion. It is recommended that further experimental research be carried out to corroborate the science of atmospheric bioaerosols to different forms of corrosion.
\end{abstract}

\section{Introduction}

Atmospheric aerosol can be chemically or biologically oriented. Sometimes, it appears as both chemically and biologically particulates that are suspended in the atmosphere. This kind of aerosols is characterized by specific sizes that can be in nanoscale. Its transportation in the atmosphere is unique because it is minute to be suspended and carried over far distances by trade winds. In atmospheric sciences, this type of aerosols significantly influences the earth's radiation balance, fog formation, cloud physics, and visibility degradation. In medicine, this type of aerosol causes respiratory disorder, lung malfunction, cancer, asthma, etc. The chemically oriented atmospheric aerosols are christened "chem-aerosol," and the biologically oriented aerosols are christened "bioaerosols."

The chem-aerosols are composed of sulfates, nitrates, carbonates, and ammoniums. It is salient to note that chem-aerosol characteristics can change rapidly in time and space depending on different prevailing circumstances in the atmosphere such as chemical mixing, particulate coagula- tion, particulate size disintegration, and chemical reaction. Offroy and Duponchel [1] stated that the chem-aerosols have sea salt-derived particles (i.e., $\mathrm{Na}_{2} \mathrm{SO}_{4}$ and $\mathrm{CaSO}_{4} \cdot 2 \mathrm{H}_{2} \mathrm{O}$ ), reacted particles (i.e., $\mathrm{NaNO}_{3}$ ), or metal-rich particles (e.g., $\mathrm{PbO} \cdot \mathrm{PbSO}_{4}$ ). According to researchers, the metal-rich particles may include $\mathrm{Al}, \mathrm{Si}, \mathrm{S}, \mathrm{Cl}, \mathrm{K}, \mathrm{Ca}, \mathrm{Ti}, \mathrm{V}, \mathrm{Cr}, \mathrm{Mn}, \mathrm{Fe}, \mathrm{Cu}, \mathrm{Zn}$, and $\mathrm{Pb}$ [2]. The component of the atmospheric aerosols makes it an interesting subject matter towards the subject of corrosion. Aside from the presence of the earth's moisture and oxygen, the chem-aerosol components can collapse corrosion protective layers over the metallic surface. Chemaerosol comes in contact with metallic through advection due to the airflow (wind), convection due to thermal air currents, and diffusion due to concentration gradient of the species, dry, and wet deposition. The most common wet and dry deposition processes occur mostly as acid rain. Figure 1 expresses the effect of atmospheric corrosion on metallic surfaces. In the United Kingdom, the annual losses due to the metallic surface's atmospheric corrosion are several hundred million pounds [3, 4]. Likewise, in the United States 


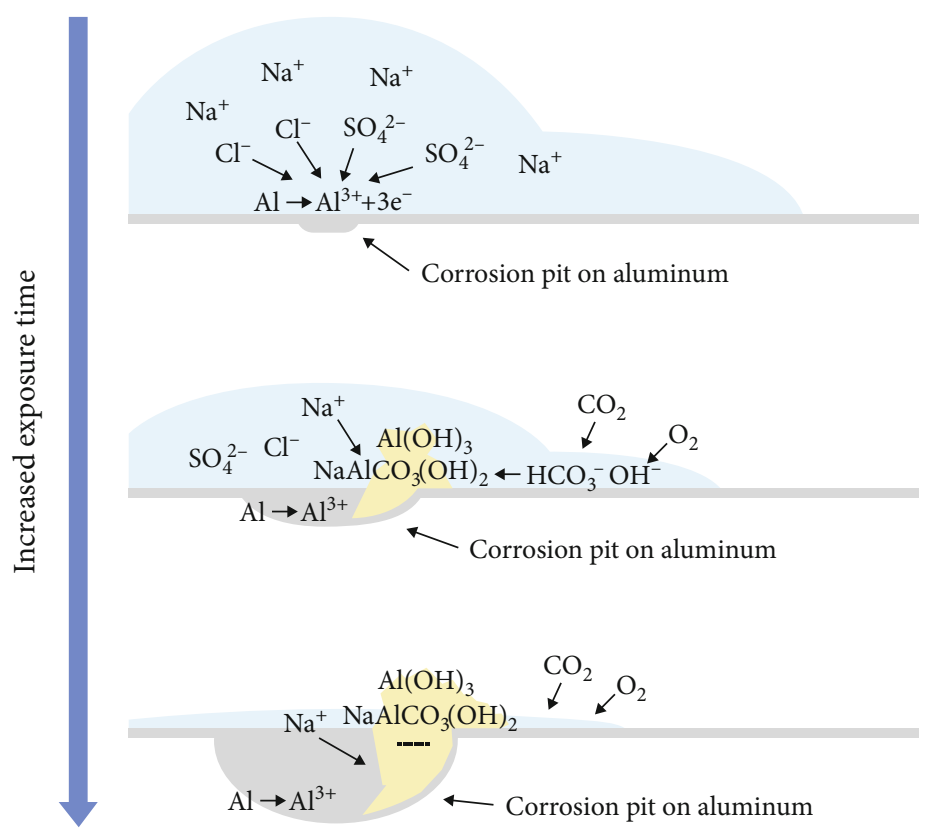

FIgURE 1: Evidence of atmospheric corrosion in metallic corrosion [5].

of America, an estimate of $\$ 100$ billion per year is spent on replacing iron-containing objects destroyed by corrosion.

Atmospheric corrosion is adjudged the most visible corrosion process, e.g., rusty bridges, rusty roofing materials, rusty gates, flagpoles, buildings and outdoor monuments, and automobile mufflers or bodies, agricultural machinery, steel structures, and fences. Electrochemical (anodic and cathodic) reactions occur in a very thin layer of water condensed on the corroding surface during the atmospheric corrosion process. If the deposited chem-aerosol is present at the surface of the metallic material, it aids corrosion faster by reducing water's thermodynamic activity. The corrosivity category for each metallic component is given below in Table 1.

Morcillo et al. [6] worked on long-term atmospheric corrosion of mild steel. They expressed the complexities of chem-aerosols on corroding metallic surfaces. For example, iron reacts with the sulfur component of the chem-aerosols (in the urban and industrial atmosphere) to form iron(II) sulfur heptahydrate (melanterite), tetrahydrate (rozenite), monohydrate, and iron(III) sulfate. Also, iron can react with chlorine-based aerosols to form iron(III) chloride, iron(II) chloride tetrahydrate, and iron(III) chloride hexahydrate [7]. The enlightened research scientists that long-time $(>50$ years) exposure of mild steel reduces oxygen within the oxide layer and not at the metal or electrolyte interface.

All the research work on atmospheric corrosion on mildsteel points to the fact that corrosion's chemical products does not depend on the years of experimentation or multiple locations the experiment was performed [8-10]. In this research, it is proposed that the volume of atmospheric aerosols triggers the corrosion rate of corrosion surfaces. The paper seeks to examine the role of atmospheric aerosols and bioaerosols in corrosion. Salient subtopics were discussed, i.e., aerosols' global atmospheric distribution, evidence of atmospheric corrosion in selected countries, significance bioaerosols, and aerosols to corrosion microstructural analysis of aerosols and a proposal for the review of atmospheric corrosion rate.

The other aspect of atmospheric corrosion is the initiation of microbially influenced corrosion (MIC) via the deposition of atmospheric bioaerosols on steel or iron. The MIC has been reported to devastating in cost of damage via corrosion of surfaces [13, 14]. The microorganisms causing MIC include bacteria, fungi, and algae. The most common microorganisms causing $\mathrm{MIC}$ is the Bacteria MIC. Bacteria MIC can be in the form of sulfate-reducing bacteria (Acidithiobacillus, Ferrobacillus ferrooxidans, Thiobacillus thioparus, Desulfovibrio, Thiobacillus concretivorus, Desulfotomaculum, etc.), sulfur/sulfide-oxidizing bacteria (prokaryotes, Beggiatoaceae, and Epsilonproteobacteria), metal-reducing bacteria (Geobacteraceae, Shewanella spp.), metal-depositing Bacteria (Leptothrix), acidproducing bacteria (Acidithiobacillus), and bacteria excreting exopolymers or slime (Klebsiella). Scientists have suggested the pattern of MIC on different types of steels and metallic alloys [15-18].

\section{Aerosol Transportation and Distribution in the Atmosphere}

The information on atmospheric aerosol transport is salient for the complete comprehension of meteorological and climatological processes and how it affects atmospheric corrosion. Stetzenbach [19] revealed that the transportation of aerosols (chem-aerosols or bioaerosols) is linked to their physical properties such as size, density, and shape of droplets or particles. The environmental factors include the magnitude of air currents, relative humidity, and 
TABLE 1: Corrosivity category of metals acc. to NBR 14643 [11, 12].

\begin{tabular}{|c|c|c|c|c|c|}
\hline \multirow{2}{*}{ Corrosivity category } & \multicolumn{5}{|c|}{ Corrosion rates of metals } \\
\hline & Units & Carbon steel & Zinc & Copper & Aluminum \\
\hline \multirow{2}{*}{$\mathrm{C}_{1}$ (very low) } & $\mathrm{g} \mathrm{m}^{-2} \mathrm{y}^{-1}$ & $0-10$ & $0-0.7$ & $0-0.9$ & \multirow{2}{*}{ Negligible } \\
\hline & $\mu \mathrm{m} \mathrm{y}^{-1}$ & $0-1.3$ & $0-0.1$ & $0-0.1$ & \\
\hline \multirow{2}{*}{$\mathrm{C}_{2}$ (low) } & $\mathrm{g} \mathrm{m}^{-2} \mathrm{y}^{-1}$ & $10-200$ & $0.7-5$ & $0.9-5$ & \multirow{2}{*}{$0-0.6$} \\
\hline & $\mu \mathrm{m} \mathrm{y}^{-1}$ & $1.3-25$ & $0.1-0.7$ & $0.1-0.6$ & \\
\hline \multirow[b]{2}{*}{$\mathrm{C}_{3}$ (medium) } & $\mathrm{g} \mathrm{m}^{-2} \mathrm{y}^{-1}$ & $200-400$ & $5-15$ & $5-12$ & \multirow{2}{*}{$0.6-2$} \\
\hline & $\mu \mathrm{m} \mathrm{y}^{-1}$ & $25-50$ & $0.7-2.1$ & $0.6-1.3$ & \\
\hline \multirow{2}{*}{$\mathrm{C}_{4}$ (high) } & $\mathrm{g} \mathrm{m}^{-2} \mathrm{y}^{-1}$ & $400-650$ & $15-30$ & $12-25$ & \multirow{2}{*}{$2-5$} \\
\hline & $\mu \mathrm{m} \mathrm{y}^{-1}$ & $50-80$ & $2.1-4.2$ & $1.3-2.8$ & \\
\hline \multirow{2}{*}{$C_{5}$ (very high) } & $\mathrm{g} \mathrm{m}^{-2} \mathrm{y}^{-1}$ & $650-1500$ & $30-60$ & $25-50$ & \multirow{2}{*}{$5-10$} \\
\hline & $\mu \mathrm{m} \mathrm{y}^{-1}$ & $80-200$ & $4.2-8.4$ & $2.8-5.6$ & \\
\hline
\end{tabular}

temperature. Emetere [20-22] did an extensive study on aerosols' transportation across one hundred communities in West Africa-West African regional scale dispersion model. The West African regional scale dispersion model (WASDM) for calculating aerosol loading over a region is expressed mathematically as

$$
\begin{aligned}
\psi(\lambda)= & a_{1}{ }^{2} \cos \left(\frac{n_{1} \pi \tau(\lambda)}{2} x\right) \cos \left(\frac{n_{1} \pi \tau(\lambda)}{2} y\right) \\
& +\cdots+a_{n}{ }^{2} \cos \left(\frac{n_{n} \pi \tau(\lambda)}{2} x\right) \cos \left(\frac{n_{n} \pi \tau(\lambda)}{2} y\right) .
\end{aligned}
$$

$a$ is the atmospheric constant obtained from the fifteen years aerosol optical depth (AOD) dataset from MISR, $n$ is the tuning constant, $\tau(\lambda)$ is the AOD of the area, and $\psi$ $(\lambda)$ is the aerosol loading. The study used fifteen years of satellite imagery dataset (Multiangle Imaging SpectroRadiometer (MISR)). The studies showed that aerosols transport at approximately $10 \mathrm{~m} / \mathrm{s}$ across the West Africa region. This result suggests that not only regions of pollution that are at risk but also communities close to the anthropogenic source would also be affected over time. For example, consider the aerosol distribution over Dori community in West Africa in Figure 2 [23]. Aerosol distribution has concentration centers that change with time and space. Figure 3 shows the satellite imagery of the global distribution of aerosols. The diagram shows that the region is highly polluted. Sudheer and Rengarajan [24] studied the atmospheric mineral dust and trace metals over the urban environment in western India (Ahmedabad) during winter. It was observed that concentrations of $\mathrm{Zn}, \mathrm{Cd}$, and $\mathrm{Pb}$ in the range of $16.5-290,0.1-5.4$, and $28-1023 \mathrm{ng} / \mathrm{m}^{3}$ in PM2.5 and $38-459,0.21-8.4$, and $48-$ $1223 \mathrm{ng} / \mathrm{m}^{3}$ in PM10 have been distributed within an aerial distance of $\sim 100 \mathrm{~km}$. Atmospheric aerosol particles are distributed over more than four orders of magnitude from $1 \mathrm{~nm}$ to about $100 \mathrm{~mm}$ and concentrations of PM2.5 and PM10 (atmospheric particles with an aerodynamic diameter less than 2.5 and $10 \mu \mathrm{m}$, respectively).

The distribution of particle numbers over particle diameter $D$, geometric mean diameter $\mathrm{dg}$, geometric standard devi- ation sg, and total number concentration $N$ is estimated using equation (1):

$$
\frac{d n}{d \operatorname{In} D}=\frac{N}{\sqrt{2 \pi} \operatorname{In} \sigma_{g}} \exp \left[\frac{\left(\operatorname{In} D-\operatorname{In} D_{g}\right)^{2}}{2\left(\operatorname{In} \sigma_{g}\right)^{2}}\right] .
$$

Here, $d n / d \operatorname{In} D$ is the number of particles per logarithmic size interval and volume of air. Kaskaoutis et al. [25] worked on aerosol transport in the northern parts of India. It was revealed that crop residue burning significantly influences aerosol properties, plume characteristics, and long-range transport over Northern India. Kannemadugu [26] also made some salient observations on the aerosol transport in the southern parts of India. It was observed that almost same factors listed above can be seen in southern and northern India, despite the reversal of winds from South West to North East of India during monsoon withdrawal. It was also observed that lesser influence of dust-related aerosol particles in south India. The research works further affirmed that geographical and meteorological factors (regional wind and weather conditions) influence air pollutants' transport and chemistry. During the changing distribution, it is expected that the aerosol undergoes chemical mixing and transformation. The coagulated atmospheric aerosol deposits (wet and dry deposition) on the metallic surfaces over the region and creates different corrosion patterns. The changing atmospheric distribution alters the size, density, and shape of particles. This result means that varying sizes of aerosols deposit on the corroding surface over time. Hence, the influence of the aerosols on the corrosion rate on the metallic surface depends on the volume, distribution, chemical, and biological properties of the deposited particles.

One of the best tools for understanding aerosol transport on a larger scale is the remote sensing technique. Some popular satellite platform for retrieving aerosol dataset is Multiangle Imaging Spectro-Radiometer (MISR), CloudAerosol lidar with Orthogonal Polarization (CALIOP) onboard the Cloud-Aerosol lidar, LIDAR (Light Detection And Ranging), and Infrared Pathfinder Satellite Observations (CALIPSO). Aerosol transportation depends on wind 


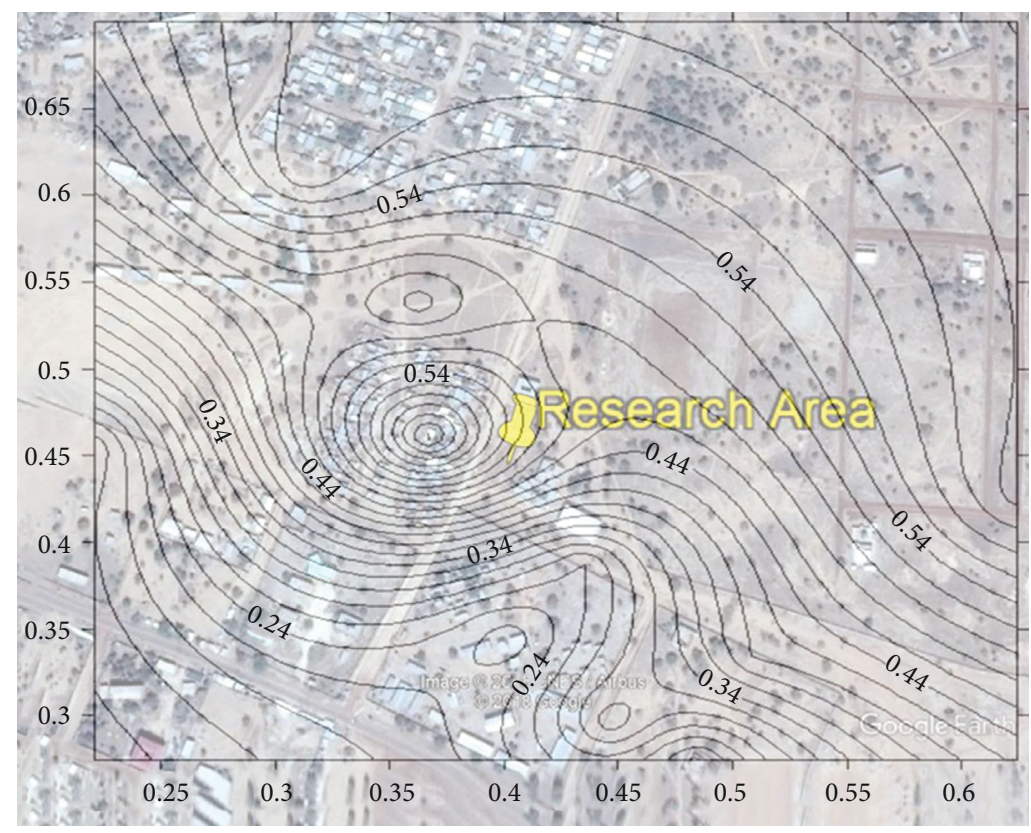

(a)

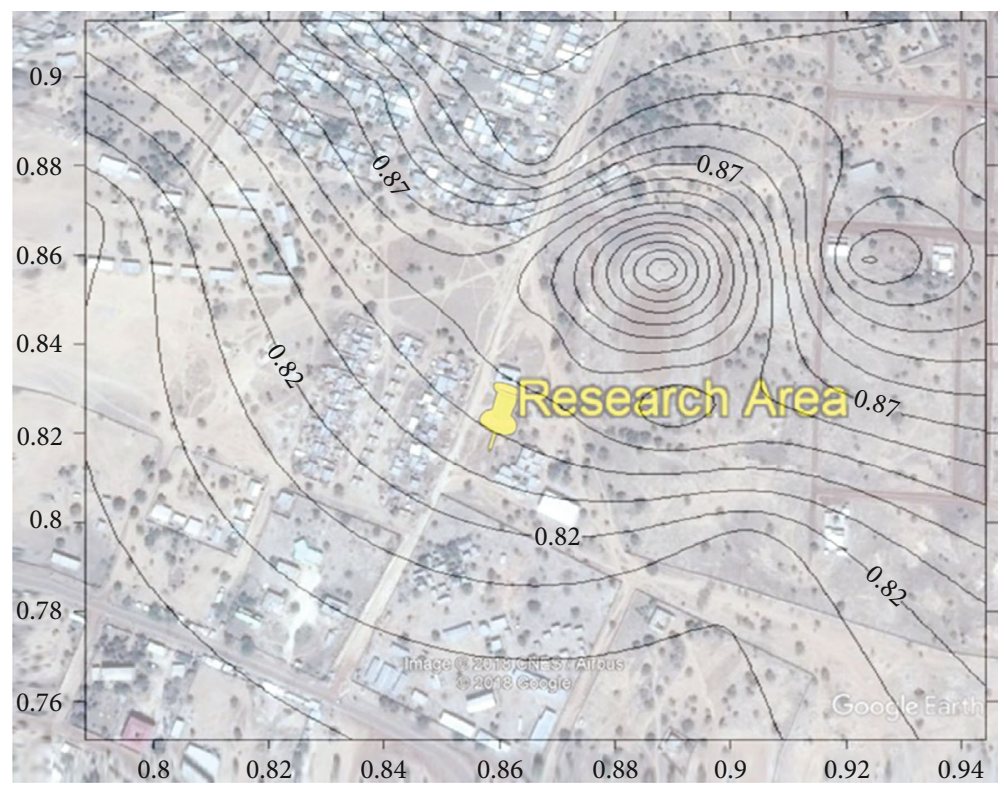

(b)

Figure 2: Aerosol distribution over the same community [23].

dynamics, along with the topography of the geographical area. Tingyao [27] corroborated this fact by postulating that the maximum height and the value of the aerosol layer's extinction coefficient close to the ground gradually decreased when moving out from urban to suburban areas where there is significant vertical mixing of air masses.

\section{Microstructural Analysis of Atmospheric Aerosols}

The atmospheric aerosols (i.e., chem- and bioaerosols) were obtained and characterized using scanning electron microscopy. Figure 4 presents the SEM images when the grains are marked at thresholds. The inverted height technique allows for the calibration of the images as presented below. The chem-aerosols (Harmattan dust) have more pores to allow for trapping of moist, etc. However, the bioaerosols are more networked, as presented in Figure 4(a). This result means that they can retain moist within their biological framework. This fact is supported in the 3D image background plot (Figure 5). The bioaerosols have different zones within themselves that can trigger different forms of corrosion on the metallic surface. The aerosol lattices are further evidenced that bioaerosols are more potent to create pit corrosion on metallic surfaces (Figure 6). 


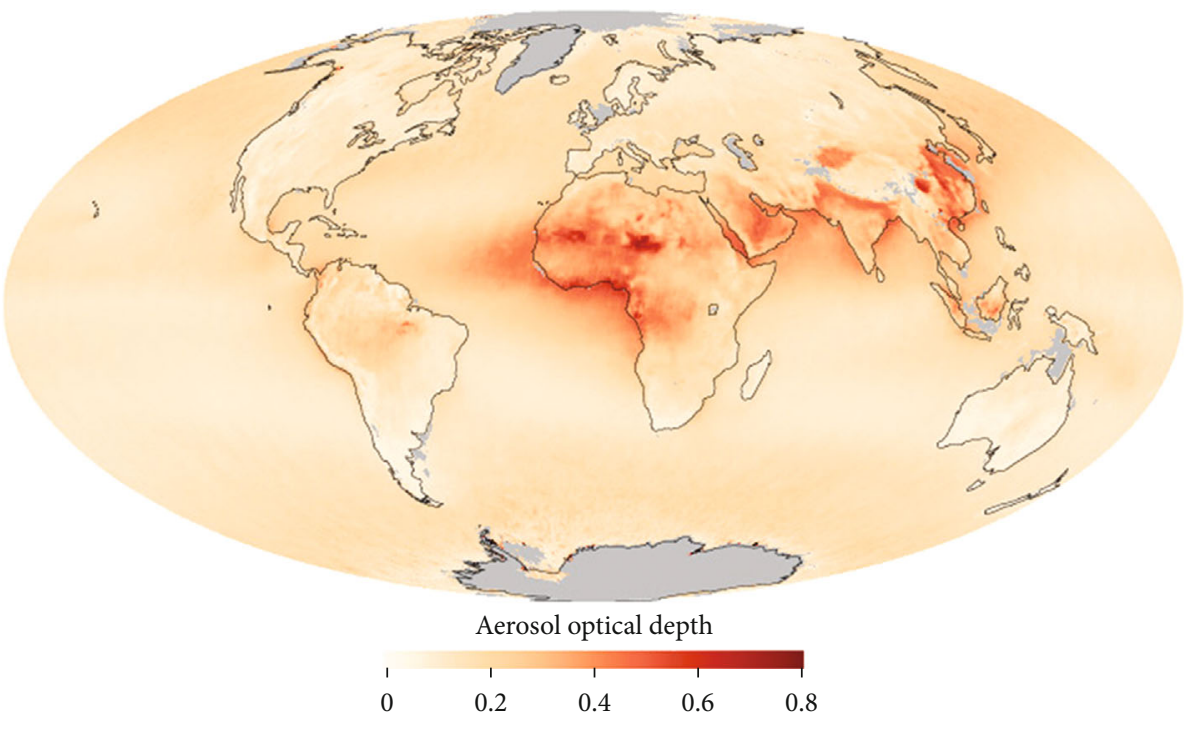

FIGURE 3: Global atmospheric aerosol distribution.

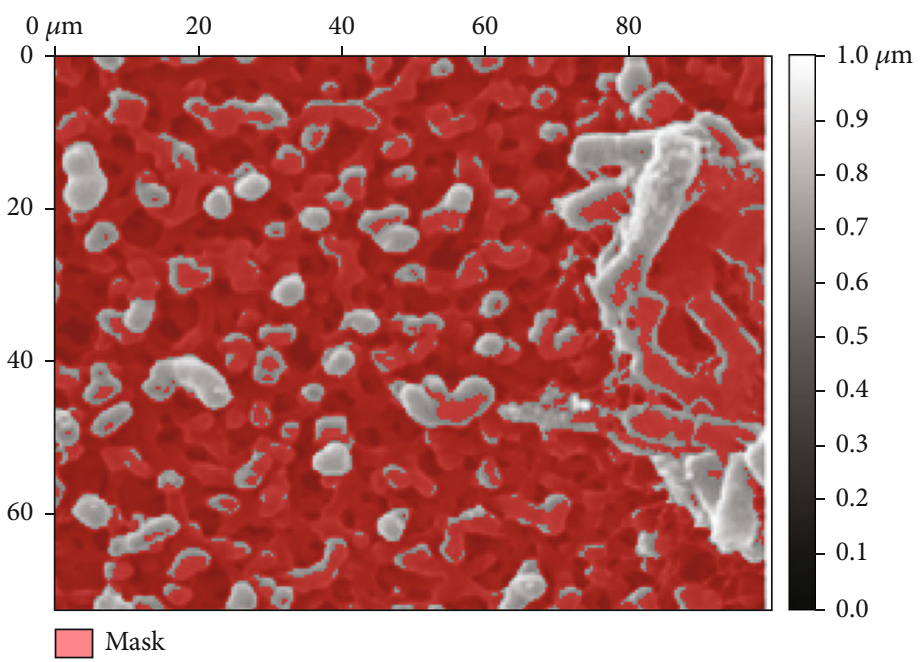

(a)

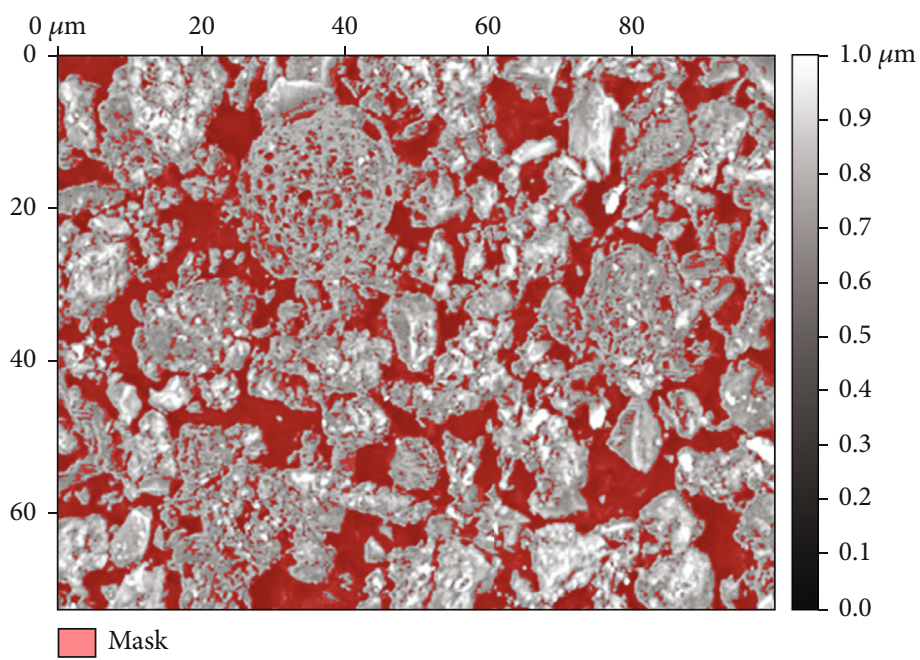

(b)

FIGURE 4: SEM of aerosols: (a) bioaerosols and (b) chem-aerosols. 


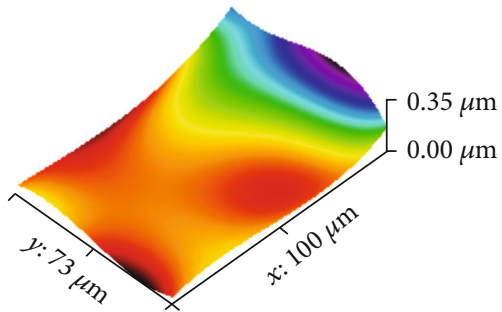

(a)

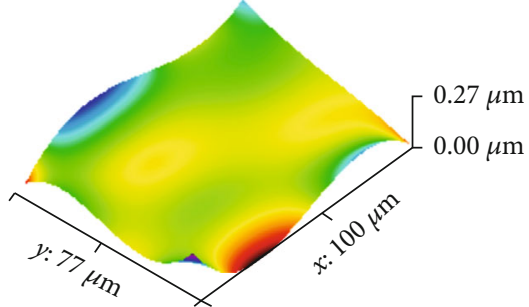

(b)

FIGURE 5: 3D background plot of aerosols: (a) bioaerosols and (b) chem-aerosols.

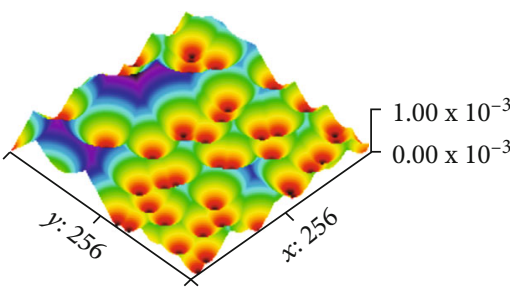

(a)

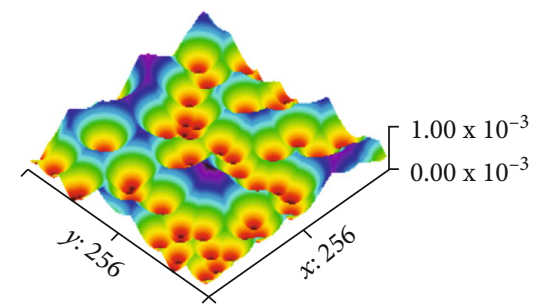

(b)

FIGURE 6: Lattices of the aerosols: (a) bioaerosols and (b) chem-aerosols.

The SEM image statistics (Table 2) reveal that bioaerosols and chem-aerosols have grain sizes of $181.940 \mathrm{~nm}$ and $192.769 \mathrm{~nm}$, respectively. The Skew and Kurtosis value of the bioaerosol is further proof that it tends to initiate pit corrosion on metallic surfaces. Other statistical parameters are further proof that the atmospheric aerosols can be uniformly deposited on the metallic surface. This result means that aside from the meteorological parameters of temperature, moisture, and relative humidity, the atmospheric aerosols play a significant role that must be quantified.

The analysis between the bioaerosols and chem-aerosols shed more light on the surface morphology of sulfatereducing bacteria (Desulfovibrio caledoniensis) and ironoxidizing bacteria (Pseudomonas sp.) on X65 steel [28]. They observe that biofilm morphology of specimen surfaces exposed to the mixed sulfate-reducing bacteria and ironoxidizing bacteria media changed with time. The bacteria were found to delaminate the structure of the steel to enhance the increase of pores and cracks that fosters corrosion. Hence, the chemical structure and size of the bioaerosol can be regarded as a salient factor in steel corrosion.

\section{Significance of Bioaerosol on Corrosion Processes}

Bioaerosols, otherwise known as primary biological aerosols (PBA), are made up of algae, archaea, bacteria, protozoa, archaea, fungal spores, and plant pollen. Like the chem-aerosols, it can be transported over long distances and up to very high altitudes because of its size $[29,30]$ that ranges from nanometers up to about a tenth of a millimeter [31]. PBA sources include municipal waste centers, terrestrial, soil, tropical rain forest, desert dust, agricultural and composting
TABLE 2: SEM image statistics.

\begin{tabular}{lcc}
\hline Statistical quantities & Chem-aerosols & Bioaerosols \\
\hline Average value: & $0.541678 \mu \mathrm{m}$ & $0.379106 \mu \mathrm{m}$ \\
RMS roughness (Sq): & $192.769 \mathrm{~nm}$ & $181.940 \mathrm{~nm}$ \\
RMS (grain-wise): & $192.769 \mathrm{~nm}$ & $181.940 \mathrm{~nm}$ \\
Average roughness (Sa): & $155.614 \mathrm{~nm}$ & $146.229 \mathrm{~nm}$ \\
Skew (Ssk): & -0.268055 & 0.562874 \\
Kurtosis: & -0.500641 & 0.294750 \\
Minimum: & $0.000000 \mu \mathrm{m}$ & $0.007843 \mu \mathrm{m}$ \\
Maximum: & $1.000000 \mu \mathrm{m}$ & $1.000000 \mu \mathrm{m}$ \\
Median: & $0.572549 \mu \mathrm{m}$ & $0.360784 \mu \mathrm{m}$ \\
Maximum peak height (Sp): & $0.458322 \mu \mathrm{m}$ & $0.620894 \mu \mathrm{m}$ \\
Maximum pit depth (Sv): & $0.541678 \mu \mathrm{m}$ & $0.371263 \mu \mathrm{m}$ \\
Maximum height (Sz): & $1.000000 \mu \mathrm{m}$ & $0.992157 \mu \mathrm{m}$ \\
Projected area: & $7695.65 \mu \mathrm{m}^{2}$ & $7265.63 \mu \mathrm{m}^{2}$ \\
Surface area: & $8580.37 \mu \mathrm{m}^{2}$ & $7685.13 \mu \mathrm{m}^{2}$ \\
Volume: & $4168.57 \mu \mathrm{m}^{3}$ & $2754.44 \mu \mathrm{m}^{3}$ \\
Variation: & $3289.81 \mu \mathrm{m}^{2}$ & $1600.26 \mu \mathrm{m}^{2}$ \\
Inclination $\theta:$ & $0.17 \mathrm{deg}$ & $0.24 \mathrm{deg}$ \\
Inclination $\varphi:$ & $-8.37 \mathrm{deg}$ & $-159.53 \mathrm{deg}$ \\
Scan line discrepancy: & 0.0783472 & 0.0870799 \\
\hline
\end{tabular}

activities, urban areas, landfill, wetlands, coastal, construction sites, and marine environments [20, 32]. PBA undergo internal and external mixing with other aerosols in the atmosphere. Hence, the resulting products are determined by the nature of air pollution in the research location. PBA accounts for around $30 \%$ of urban and rural air $[33,34]$. Also, bioaerosol makes up to 5 to $34 \%$ of indoor particulate matter air 


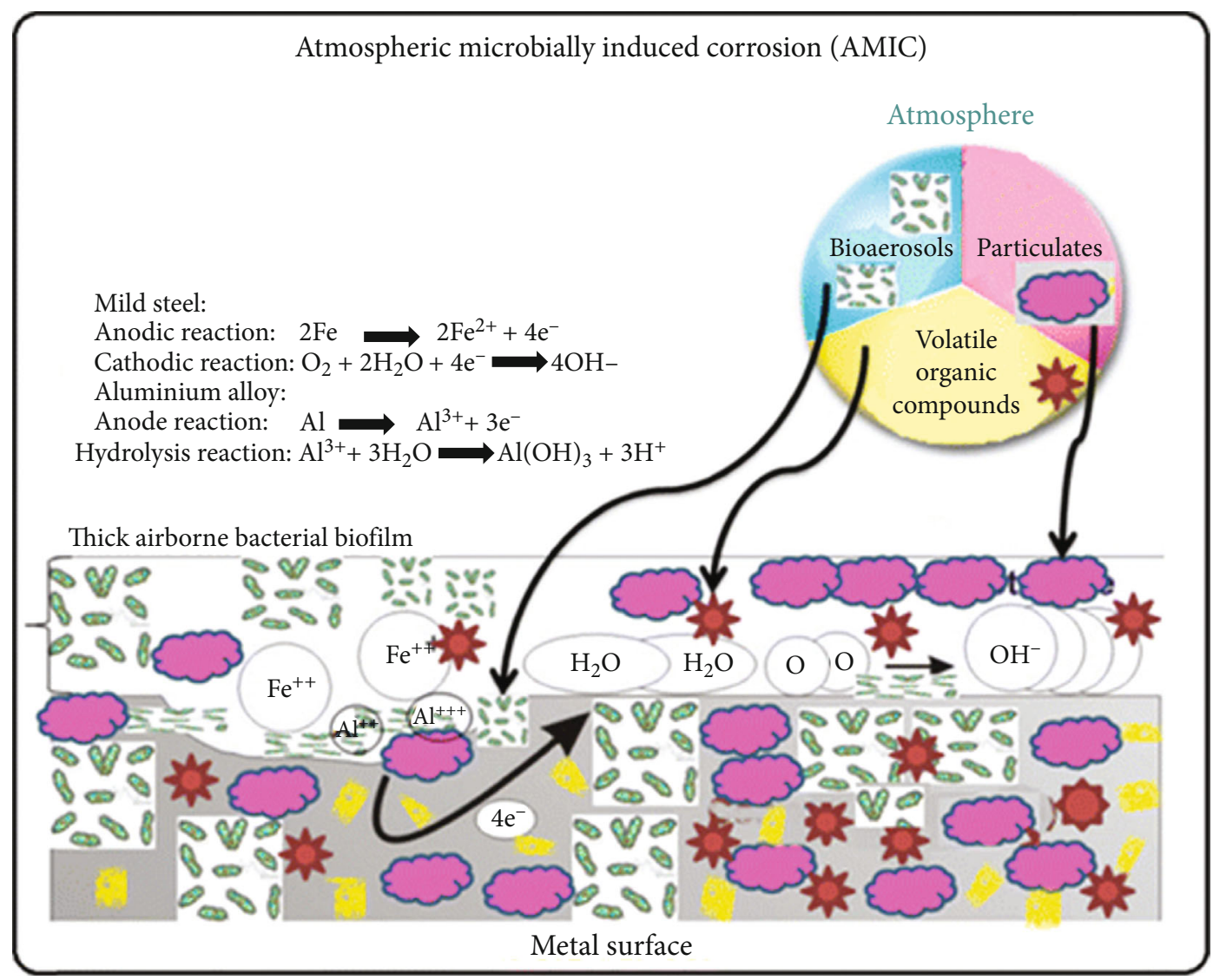

FIGURE 7: Atmospheric microbially induced corrosion [40].

pollution [35]. Schumacher et al. [36] revealed that bioaerosol concentration is low in the afternoon and high at night and early morning. This trend is related to the relative humidity in the atmosphere. This fact is true for all types of atmospheric aerosols (chem-aerosols and bioaerosols).

The biological characterization of bioaerosols via DNA analysis (Next-Generation Sequencing (NGS) technologies) and RNA analysis (genomics and transcriptomics) revealed that it is mainly fungal phyla [37]. Cai et al. [38] revealed that bioaerosols are made up of "viruses (enteric viruses, Noro-and rotaviruses, respiratory virus such as influenza and coronaviruses), bacteria (staphylococci, legionellae, tuberculous and nontuberculous), bacterial spore formers (Clostridium difficile and Bacillus anthracis) and fungi (Aspergillus, Penicillium, and Cladosporium spp., fungal spores, hyphae, fungal allergens, Stachybotrys chartarum)." Després et al. [33] revealed that when PBA is inhaled in human, there is the transference of DNA concentrations as high as $\sim 0.1-$ $1 \mu \mathrm{g}$ per day, which corresponds to $\sim 10^{14}-10^{15}$ bp or $\sim 107-$ $10^{8}$ bacterial genomes or $\sim 104-10^{5}$ human genomes. Recent advancements in corrosion science had revealed that DNA activates corrosion. With $\sim 10^{7}-10^{8}$ bacterial genomes or $\sim 104-10^{5}$ human genomes in bioaerosols, bioaerosols' chemical reaction on corrosion surfaces will be faster than the chem-aerosols.

In other words, bioaerosol is a complex heterogeneous mix of distinct biological materials. These significant proper- ties of bioaerosols make it unique to give dynamic results to its effect on corrosion surfaces. This result further proves that atmospheric corrosion cannot only be measured by exposure to moisture and oxygen. The volume of aerosols is a vital component to be considered in the atmospheric corrosion of metal. Figure 7 reveals that aside from moisture and oxygen, bioaerosols are quite potent to sustain corrosion in the absence of moisture and oxygen. This result is because some of its components (highlighted above) can survive harsh conditions [39].

As proven in human health, exposure to bioaerosols has different dynamics to exposure to chem-aerosols. Chemaerosols can be involved in chemical mixing and reaction, but bioaerosols will maintain their biological components despite the chemical transformation. In other words, metallic surfaces that have been infested by bioaerosols have higher corrosion rates than the chem-aerosols. This fact can be substantiated in the corrosion duration and corrosion resistance of materials (such as mild steel and aluminum alloy) as reported by Aruliah et al. [41] and Fuente et al. [42]. Aruliah et al. [41] experimented using a bacterial bioaerosol whose components are Bacillaceae, Staphylococcaceae, and Paenibacillaceae within 150 days. The corrosion resistance of aluminum alloy and mild in the experiment was given as $1.37 \mathrm{mg} / \mathrm{cm}^{2}$ and $26.13 \mathrm{mg} / \mathrm{cm}^{2}$, respectively. In Fuente et al.'s [42] experimentation, mild steel was exposed to atmospheric aerosols for 4-6 years under four locations, i.e., rural, 
urban, industrial, and marine. The atmospheric aerosols in the research site were mainly $\mathrm{SO}_{2}$ and mildly $\mathrm{Cl}^{-}$. It was observed that the corrosion ranged between 7.5 and $92.6 \mu \mathrm{m}$.

Riu et al. [43] experimented with proof that the thickness of surface oxide films positively impacts titanium alloys' corrosion resistance. These surface oxides are prepared via the increase of oxygen concentration to about $80 \%$. This technique was said to replace the surface oxidation technique. In this sense, when anaerobic bioaerosols that have a bacterial composition, such as Nocardia sp., Pseudomonas aeruginosa, Mycobacterium tuberculosis, and Bacillus sp., etc., come in contact with this type of coated titanium alloy, it is expected that the corrosion rate will be enhanced.

Macdonald and Gibbons [44] worked on the atmospheric corrosion of austenitic, ferritic, and martensitic in eight Canadian atmospheres. They observed that there was high corrosion in the atmosphere where industries were cited. Hence, they concluded that high levels of $\mathrm{SO}_{2}$ in the atmosphere were observed to cause high corrosion. The duplex stainless steels are made up of chromium (20.1-25.4 wt\%) and nickel (1.4-7 wt\%), austenitic grades. In other to prevent corrosion, molybdenum (0.3-4 wt\%) and nitrogen are added. Molybdenum, nitrogen, and chromium are usually added to most stainless steels (ferric, martensitic, and austenitic stainless steel), to improve the corrosion resistance $[45,46]$. Almanza et al. [47] had also added that the formation of titanium oxide layer helps improved the corrosion of Ti-6Al-4 V alloys. However, Sukanya et al. [48] have shown that despite chromium, molybdenum, and nitrogen, stainless steel's atmospheric corrosion is a reality based on alloying element level, surface roughness, surface treatment, and microclimate. The effect of bioaerosols on stainless steel can be devastating, based on the composition of bioaerosols. For example, anhydrous methanol has been reported to cause stress-corrosion-cracking (SCC) in titanium [49]. If the atmosphere has a significant percentage of atmospheric methane, it is possible for bioaerosols that have the methanotrophic bacterial to produce methanol [50] that would condense on any titanic alloy to cause SCC.

Zhigao et al. [51] worked on the atmospheric corrosion impacts on carbon steel (Q235) under varying exposure conditions such as volume and $\mathrm{pH}$ of rainfall, the concentration of sulfur (IV) oxide and chlorine, temperature, and relative humidity. It was observed that the exposure duration of the carbon steel to the atmospheric condition impacted the corrosion on the material. Aside from the weight variation, it was reported that the morphology of the material changed from irregular particles to rod shapes that signifies the progression of corrosion. Sun et al. [52] investigated the solution to atmospheric corrosion in steels. Alloy steels with different amounts of chromium content were investigated. It was observed that the higher the chromium content, the lower the corrosion rate. Though it was proven that higher chromium content has a significant impact on $\mathrm{Fe}_{3} \mathrm{O}_{4}$ content in the rust layer, it is salient to note that the increase in chromium content consistently increases the steel's carbon content. An increase in carbon content may alter particular steel specification as its tendency to form martensite.

\section{The Need to Review the Atmospheric Corrosion Rate Model}

The Pourbaix governs the behavior of the phenomenon of atmospheric corrosion of metals:

$$
P=K \cdot t^{n}
$$

$P$ is the loss of thickness of the metal in $\mu \mathrm{m}$ or weight loss $(g), t$ is the exposure time in months or years, and $K$ and $n$ are constants calculated by logarithmic linearization. This idea seems to be generic as it reflects in corrosion models. Sinnott [53] postulated that corrosion rate is dependent on the density of the corrosive fluid (velocity of the corrosive fluid $(V)$, the viscosity of the corrosive fluid $(\mu)$, exposure time of the species $(t)$, and area of the species in contact with the fluid $(A)$ ).

From the theoretical corrosion rate model (equation (4)), Wan [54] and Gibbings [55] derived the experimental corrosion rate model using the Buckingham-Pie technique as shown in equation (5).

$$
\begin{aligned}
& R_{c}=A_{f}\left(\frac{V \cdot t \cdot \mu}{A \cdot \rho_{o}}\right), \\
& R_{c}=A_{f}\left(\frac{W_{L}}{t \cdot A \cdot \rho_{o}}\right),
\end{aligned}
$$

where $A_{f}$ is the dimensionless corrosion rate correction factor, $V$ is the velocity of the corrosive fluid $(\mathrm{m} / \mathrm{s}), W_{L}$ is the weight loss of the specie $(\mathrm{kg}), t$ is the exposure time (yrs), $A$ is the area of species in contact with the corrosive fluid $\left(\mathrm{m}^{2}\right), \rho_{o}$ is the density of the specie $\left(\mathrm{kg} \cdot \mathrm{m}^{-3}\right)$, and $\mu$ is the viscosity of the corrosive fluid $\left(\mathrm{Ns} / \mathrm{m}^{2}\right)$.

Portella et al. [56] worked on atmospheric aerosols' impact on the corrosion rate of metallic surfaces. The experiment was carried out under local climatic conditions. They adopted the corrosion rate equation by the American Society for Testing and Materials [57]:

$$
R_{c}=\frac{K \cdot M}{S \cdot t \cdot \rho}
$$

where $K$ is the constant which determines the corrosion rate, $M$ is the weight loss (in grams), $S$ is the area of the specimen in $\mathrm{cm}^{2}, t$ is the exposure time in hours, and $\rho$ is the specific mass in $\mathrm{g} / \mathrm{cm}^{3}$. For corrosion experiment on steel in acid $3.5 \% \mathrm{NaCl}$ solution, the value of $K$ was made $8.76 \times 10^{4}$ [58].

There was recently much research on corrosion prediction models $[15,59,60]$. The most popular model is the grey model GM $(1,1)$. The mathematical framework of the model is presented as

$$
\frac{d x(t)}{d t}=a x(t)+b
$$

where $a$ and $b$ are unknown parameters. The basis of usage of this model, as shown in [58], further affirms that the earlier 


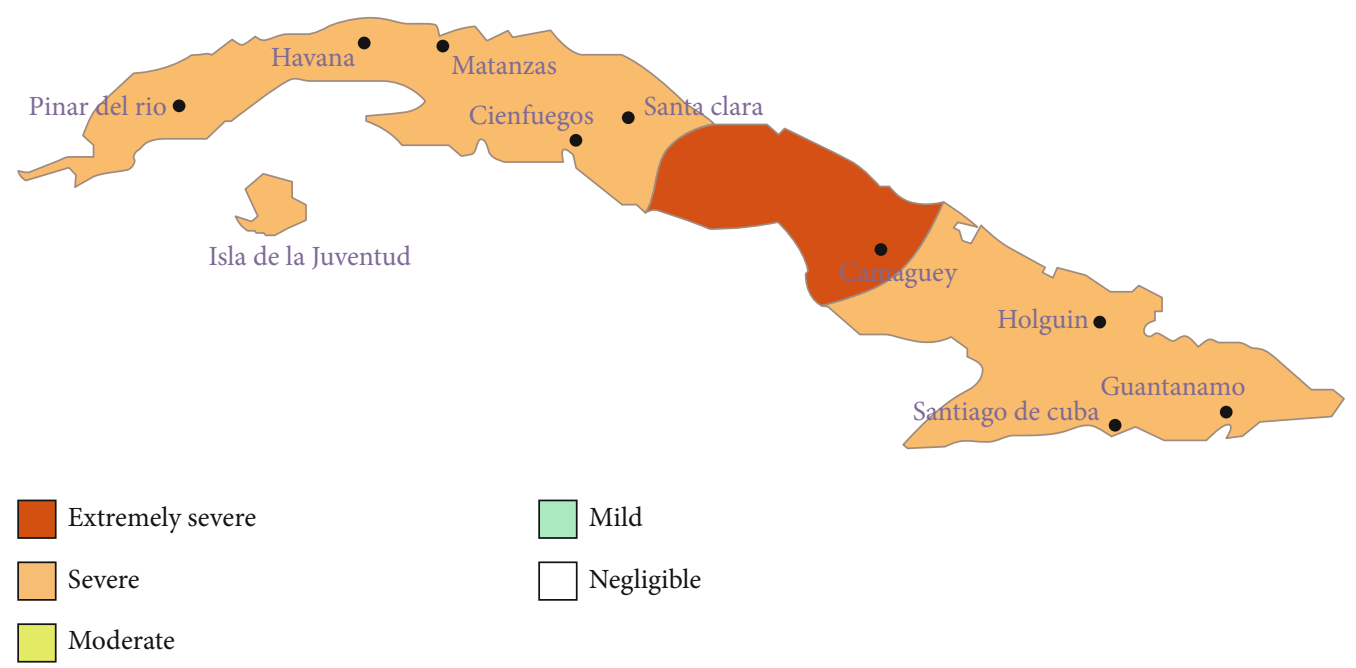

FIgURE 8: Atmospheric corrosion in Cuba [64].

postulation of Sinnott [53] is the general idea used in a corrosion work.

Guma and James investigated the atmospheric corrosion on mild steel in different environments (i.e., riverside, metropolis, and cities) around the high aerosol concentration areas of northern Nigeria [61]. The primary environmental parameter in the study area are the average relative humidity of 51.3, the average rainfall of $1323 \mathrm{~mm}$ [62], the average temperature of $25.2^{\circ} \mathrm{C}$, and the National Ambient Air Quality Standard (NAAQS) threshold range of 10-20 ppm [63]. It was observed that corrosion rates on the mainland ranged from 0.007 to $0.092 \mathrm{~mm} / \mathrm{yr}$. They conclude that environmental forces hugely impact the corrosion of carbon steel.

In this paper, we postulate that the corrosion rate for atmospheric initiated corrosion must include the quantity or volume of the aerosol (aerosol loading) of the geographical area for the following reasons:

(1) Air pollution is agreed to be very significant in the corrosion process. It must also be included in the basic corrosion rate calculation. Morcillo et al. [64] and CorrosionDoctor [65] had individually showed that air pollution could be significantly used to classify atmospheric corrosivity over a geographical enclave, as shown in Figures 8 and 9. The experimentation that was adopted by the researcher mentioned above followed the NBR and ASTM standards. If these works are accepted as standards for classifying corrosion [65], there is the need to modify the corrosion model

(2) From notable research works [21-23, 25, 27], aerosols are the main determinants of meteorological and climatological processes. Hence, while environmental factors are considered, there is the need to situate the trigger factor-atmospheric aerosols properly. Since it was proven that atmospheric corrosion could occur at a temperature below $0^{\circ} \mathrm{C}$ (ISO 9223 stan-

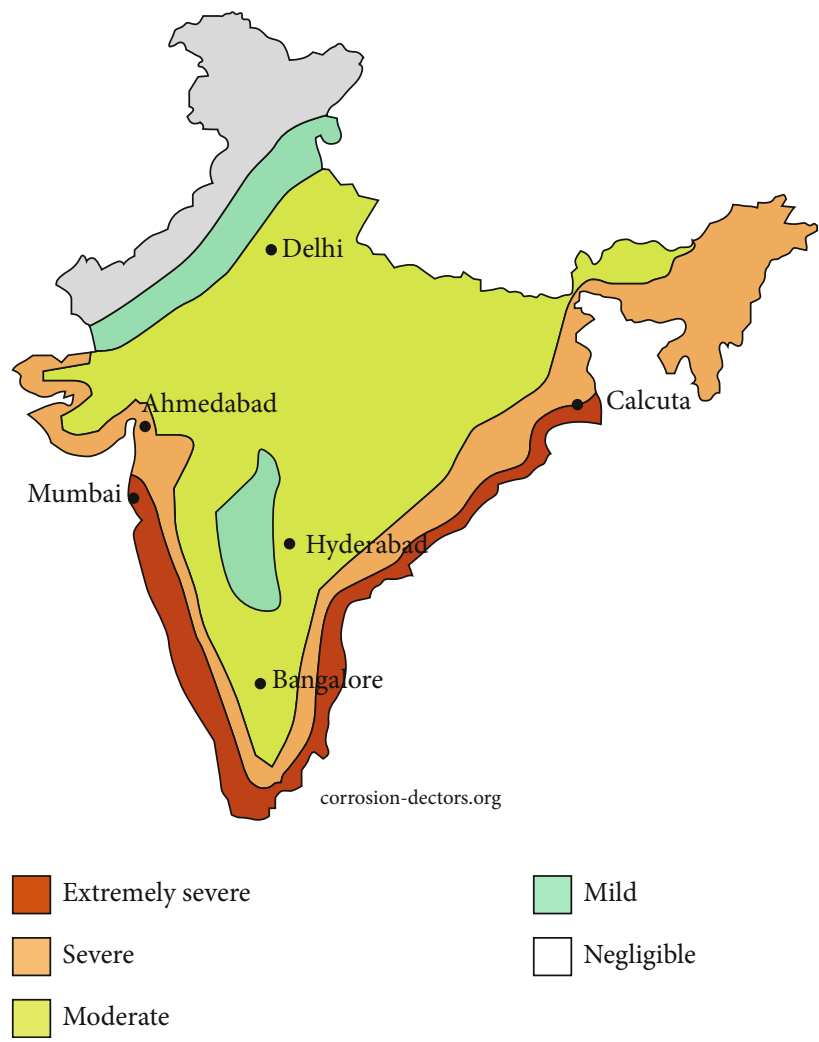

Figure 9: Atmospheric corrosion in India [64].

dard), it is logical to infer that aerosol plays a significant role in atmospheric corrosion

(3) The characterization of chem-aerosols and bioaerosols using scanning electron microscopy is evidence that aerosol is structured to trap moisture to initiate corrosion in metals

(4) Bioaersol deposition on metallic surfaces triggers the microorganism initiated corrosion [66] 

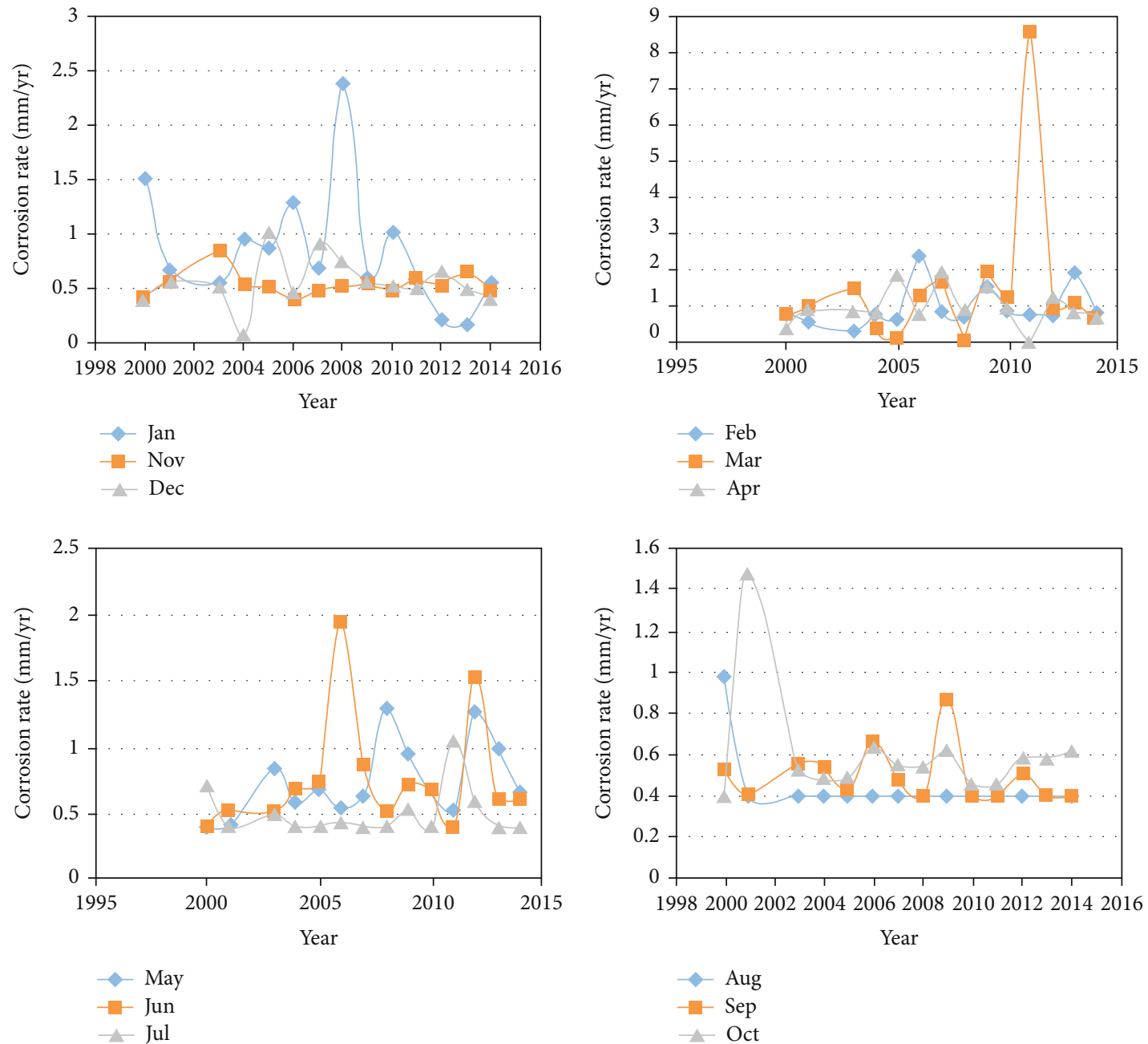

Figure 10: Atmospheric corrosion rate of iron within four seasons.

Vasconcelos et al. [67] gave a prediction model of atmospheric corrosion rate by mainly considering aerosols. This idea is instructive. However, it is localized to the geographical area under consideration. The two corrosion rate equations are listed as equations (8) and (9) for the Canary Islands (Spain) and the Gulf of Mexico.

$$
R_{c}=2.49+1.59 \mathrm{SO}_{2}+0.96 \mathrm{CI},
$$

where $R_{c}$ is expressed in micron and the concentration of chlorides and $\mathrm{SO}_{2}$ in $\mathrm{mg} /\left(\mathrm{m}^{2}\right.$ day $)$.

$$
R_{c}=0.228 \mathrm{TOW}+0.290 \mathrm{CI}+0.410 \mathrm{SO}_{2},
$$

where $R_{c}$ comes in $\mathrm{mg} /\left(\mathrm{m}^{2}\right.$ year), the concentration of chlorides and $\mathrm{SO}_{2}$ in $\mathrm{mg} /\left(\mathrm{m}^{2}\right.$ day $)$, and $\mathrm{TOW}$ in hours/year.

Emetere et al. [68] revealed a new atmospheric corrosion rate could be incorporated into the electrochemical corrosion method. The beauty of the model is that it can theoretically quantify atmospheric corrosion that has been initiated by atmospheric aerosols. The mathematical framework is given as

$$
\mathrm{CR}\left(\frac{\mu \mathrm{m}}{\mathrm{yr}}\right)=
$$

where $k$ is a conversion factor $\left(3.27 \times 10^{6} \mu \mathrm{m} \cdot \mathrm{g} \cdot \mathrm{A}^{-1} \cdot \mathrm{cm}^{-}\right.$ $\left.{ }^{1} \cdot \mathrm{yr}^{-1}\right), i_{\text {corr }}$ is the corrosion current density in $\mu \mathrm{A} / \mathrm{cm}^{2}$ (calculated from the measurements of $R_{p}$ ), EW is the equivalent weight, and $d$ is the density of Alloy 22 $\left(8.69 \mathrm{~g} / \mathrm{cm}^{3}\right)$. In this study, iron's corrosion current density was considered, and it is given as $3.2 \times 10^{-3} \mu \mathrm{A} / \mathrm{cm}^{2}$. The EW of iron is given as 27.9225 .

5.1. Theoretical Quantification of Atmospheric Aerosol Initiated Corrosion Rate. Huzni et al. [69] worked on the exposure of low carbon structural steel in industrial zones. The atmospheric corrosion reveals that an average corrosion rate of low carbon steel for each profile within the industrial zones is different. Though the region's pollution concentration was not given in the literature, it can be ascribed to the uneven spatial distribution on the environmental factors 

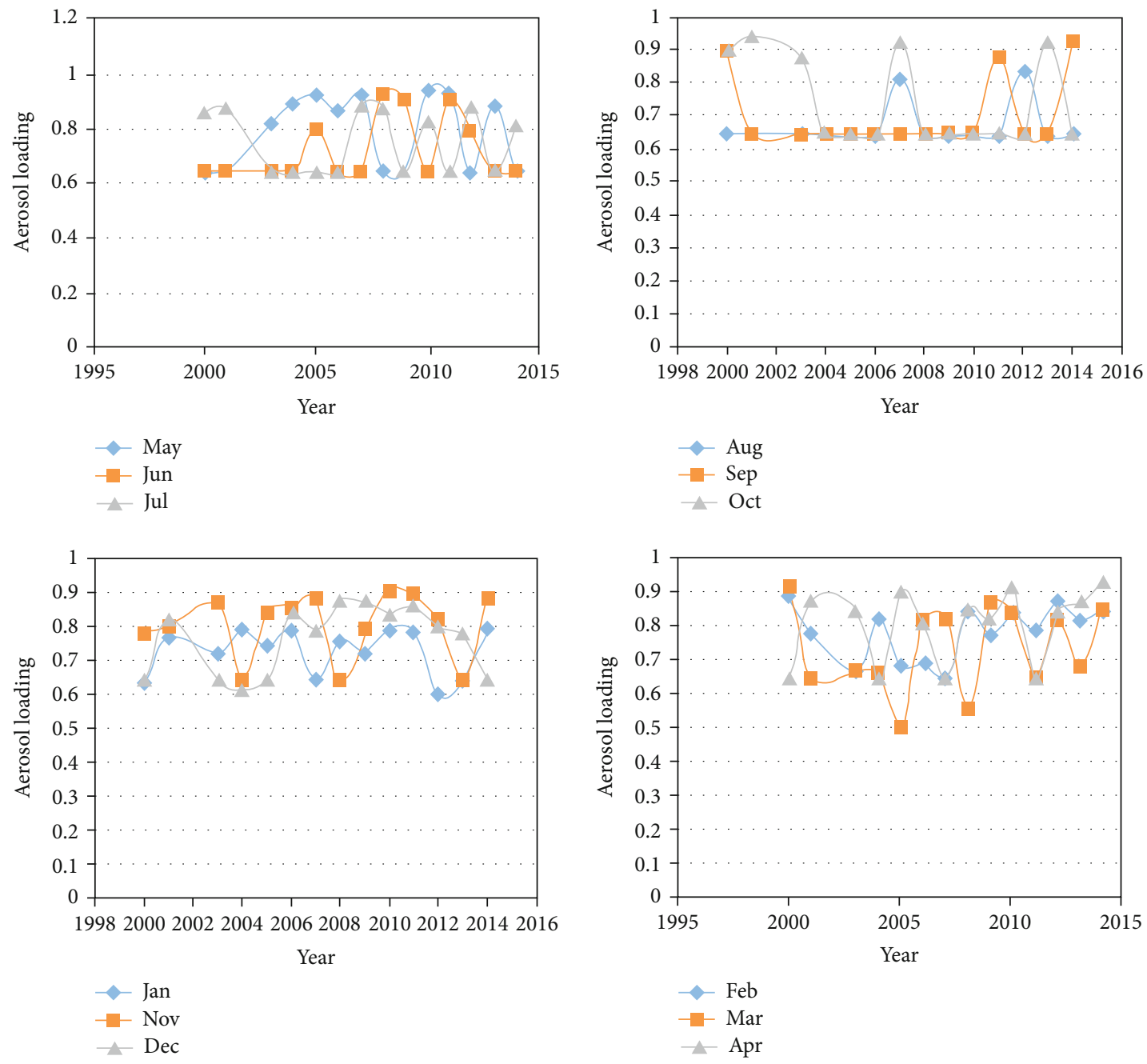

Figure 11: Aerosol loading within four seasons.

due to topography, wind dynamics, seasons, pollution sources (e.g., chlorides come from natural airborne salinity, nitrogen oxides, and sulfur oxides), etc.

This section adopts the ISO 9223 standards specifying the location, composition, and certain other factors [70]. The location of the study is Tingrela. Tingrela is located in Cote d'Ivoire on longitude and latitude of $16.0758^{\circ} \mathrm{E}$ and $8.5915^{\circ}$ N. Fifteen years (2000-2014) aerosol dataset was obtained from Multiangle Imaging Spectro-Radiometer (MISR). Equation (10) was adopted on the assumption that aerosols (chem- and bioaerosols) are mixed; $90 \%$ of the aerosols in the atmosphere are deposited uniformly on the earth surface; and the iron metal surfaces are considered because most of the roofs are iron roof materials. The dataset is divided into four major groups, i.e., early wet season (May, June, and July), late wet season (August, September, and October), early dry season (November, December, and January), and late dry season (February, March, and April). The corrosion rate is presented in Figure 10.

It is observed that the aerosol initiated corrosion rate is higher in the dry season than in the wet season. This result supports the information provided in the microstructural analysis of aerosols. Also, the corrosion rates increased steadily from November to April. The spikes in the graphs reveal moments where air pollution is highest. In the wet season, it is observed that the months May and June had the highest atmospheric corrosion rate. The lowest atmospheric corrosion during the wet season is July and August. This result is related to the break-in precipitation over the region. In other words, atmospheric corrosion fluctuates seasonally.

The aerosol loading over the geographical location is presented in Figure 11.

The aerosol loading over the location shows more aerosol loading in the early and late dry seasons. This trend is because there are lots of Harmattan dust influx from the Sahara Desert that increases the aerosol loading over the location. The aerosol loading starts decreasing in the early wet season. This trend is because aside from the reduced Sahara dust influx, the rainfall and cloud formations during that period reduce the aerosol content in the atmosphere [21, 22]. The increase in aerosol loading is found to influence the atmospheric corrosion within the period. From the aerosols' microstructural analysis, it is salient to know the aerosol sizes to ascertain if there 

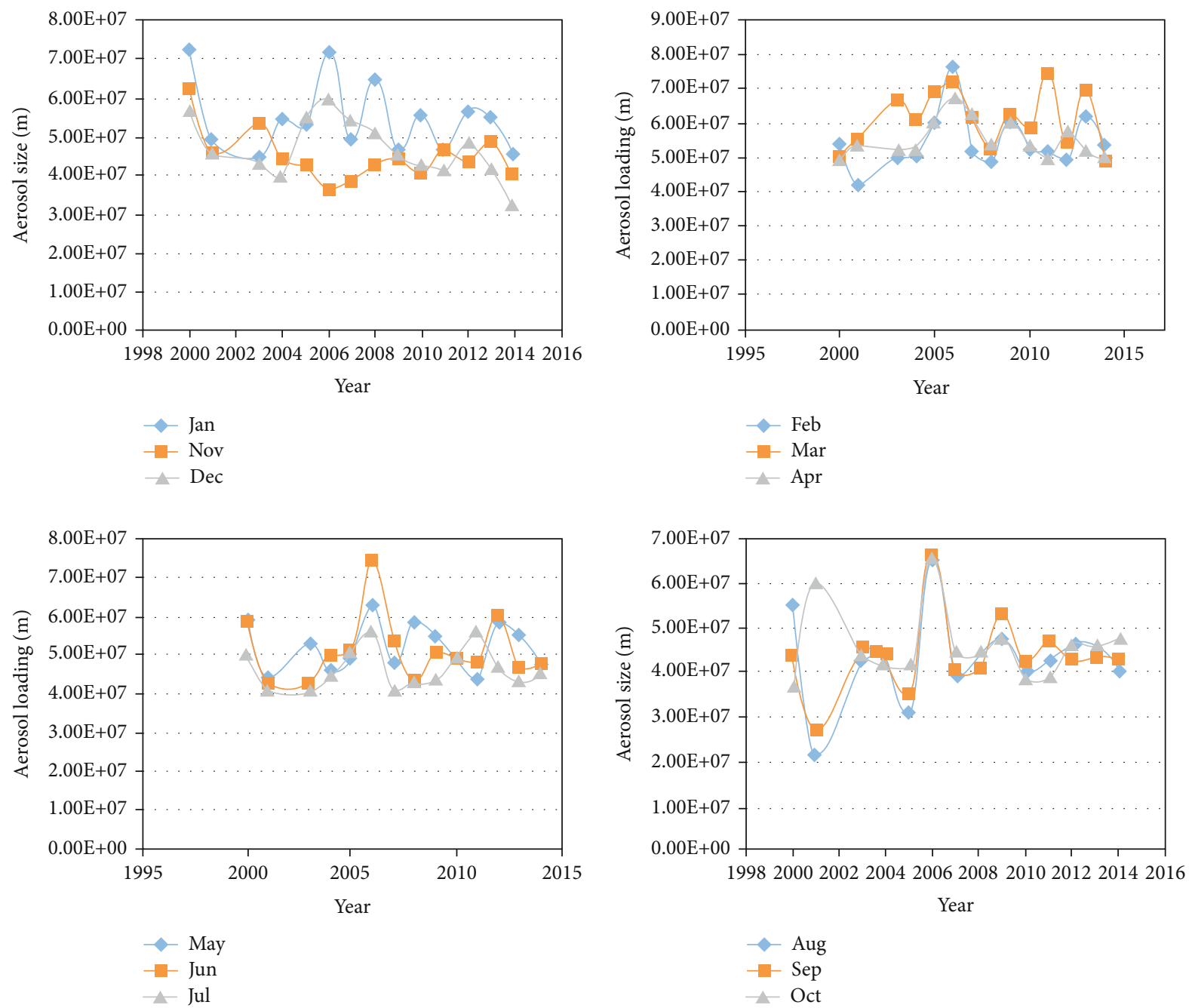

FIgURE 12: Aerosol size within four seasons.

would be more formation of "aerosol traps." This study proposes that the aerosols have "aerosol traps" that conserve early morning moist. The aerosol sizes are presented in Figure 12.

It is observed that though no clear difference exists in the aerosol sizes in the four seasons, there is still a slight understanding that aerosol size has more tendencies to be higher in dry seasons. This result means more extensive "aerosol traps" to sustain or kick-start corrosion in metallic surfaces.

\section{Conclusion}

In this paper, it has been shown that though environmental factors are salient for atmospheric corrosion, the inherent properties of bioaerosol make it essential to be considered in recent research on corrosion. The microstructural analysis of metallic surfaces affirms that bioaerosols and aerosols have the inherent properties of acting as traps to sustain a moist state during corrosion in the dry season. The bioaerosols were seen to be more active to initiate corrosion in metals. The microstructural analysis shows that bioaerosol- dominated corrosion may most likely yield the pit corrosion and stress corrosion condition. Despite the low precipitation in the dry season, it was reported that the aerosol initiated corrosion rate was higher in the dry season than in the wet season. The volume and sizes of the atmospheric aerosols have significance also on the atmospheric corrosion rate. The study adopted the incorporation of the aerosol parameter in the corrosion rate model. It is recommended that further experimental research be carried out to corroborate the science of atmospheric corrosion. The outcome of the research would help in preventing atmospheric corrosion to a large extent.

\section{Data Availability}

The satellite dataset used for this study can be found at https://10dup05.larc.nasa.gov/L3Web/view.

\section{Conflicts of Interest}

The authors declare no conflict of interest. 


\section{Acknowledgments}

The authors appreciate Covenant University for the partial sponsorship. The authors acknowledge MISR for the primary dataset.

\section{References}

[1] M. Offroy and L. Duponchel, "Chapter 15 - Super-resolution in vibrational spectroscopy: from multiple low-resolution images to high-resolution images," Data Handling in Science and Technology, vol. 30, pp. 477-517, 2016.

[2] L. Meng, L. Guo, and Z. Guo, "Separation of metals from metal-rich particles of crushed waste printed circuit boards by low-pressure filtration," Waste Management, vol. 84, pp. 227-234, 2019.

[3] M. Natesan, G. Venkatachari, and N. Palaniswamy, "Corrosivity and durability maps of India," Corrosion Prevention and Control, vol. 52, pp. 43-66, 2015.

[4] R. W. Revie, Uhlig's Corrosion Handbook, Wiley, New York, 2nd edition, 2000.

[5] X. Chen, J. Wang, D. Chen, S. Zhong, and X. Wang, "Effect of $\mathrm{Na}$ on early atmospheric corrosion of Al," Acta Metallurgica Sinica, vol. 55, no. 4, pp. 529-536, 2019.

[6] M. Morcillo, E. Almeida, M. Marrocos, and B. Rosales, “Atmospheric corrosion of copper in Ibero-America," Corrosion, vol. 57, no. 11, pp. 967-980.

[7] C. Arroyave and M. Morcillo, "Atmospheric corrosion products in iron and steels," Trends in Corrosion Research, vol. 2, pp. 1-16, 1997.

[8] M. Yamashita, K. Asami, T. Ishikawa, T. Ohtsuka, H. Tamura, and T. Misawa, "Characterization of rust layer on weathering steel exposed to the atmosphere for 17 years," Zairyo-to-Kankyo, vol. 50, no. 11, pp. 521-530, 2001.

[9] K. Asami and M. Kikuchi, "In-depth distribution of rusts on a plain carbon steel and weathering steels exposed to coastalindustrial atmosphere for 17 years," Corrosion Science, vol. 45, no. 11, pp. 2671-2688, 2003.

[10] D. C. Cook, "Spectroscopic identification of protective and non-protective corrosion coatings on steel structures in marine environments," Corrosion Science, vol. 47, no. 10, pp. 2550-2570, 2005.

[11] NBR Associação Brasileira de Normas Técnicas, NBR 14643: "Corrosão atmosférica - classificação da corrosividade de atmosferas", NBR, Rio de Janeiro, 2002.

[12] DIN EN ISO 12944-2, “Atmospheric corrosion,” December 2019, https://www.icorr.org/wp-content/uploads/2017/06/ CEDWorkingDay2018Presentation_SLyon.pdf.

[13] I. B. Beech and I. A. Sunner, "Sulphate-reducing bacteria and their role in corrosion of ferrous materials," in SulphateReducing Bacteria: Environmental and Engineered Systems, L. L. Barton and W. A. Hamilton, Eds., pp. 459-482, Cambridge University Press, Cambridge, United Kingdom, 1st edition, 2007.

[14] H. C. Flemming, "Mikrobielle werkstoffzerstörung - grundlagen: ökonomisch-technischer überblick," Materials and Corrosion/Werkstoffe und Korrosion, vol. 45, no. 1, pp. 5-9, 1994.

[15] S. W. Dean and D. B. Reiser, Corrosion, NACE International, Houston, 2000, Paper no. 455.

[16] W. Lee, Z. Lewandowski, M. Morrison, W. G. Characklis, R. Avci, and P. H. Nielsen, "Corrosion of mild steel under- neath aerobic biofilms containing sulfate-reducing bacteria Part II: at high dissolved oxygen concentration," Biofouling, vol. 7, no. 3, pp. 217-239, 1993.

[17] S. J. Salgar-Chaparro, A. Darwin, A. H. Kaksonen, and L. L. Machuca, "Carbon steel corrosion by bacteria from failed seal rings at an offshore facility," Scientific Report, vol. 10, article 12287, 2020.

[18] T. Černoušek, R. Shrestha, H. Kovářová et al., "Microbially influenced corrosion of carbon steel in the presence of anaerobic sulphate-reducing bacteria," Corrosion Engineering, Science and Technology, vol. 55, no. 2, pp. 127-137, 2020.

[19] L. D. Stetzenbach, "Introduction to Aerobiology," in Chapter 72. In: Manual of Environmental Microbiology, C. J. Hurst, R. L. Crawford, G. Knudsen, M. McInerney, and L. D. Stetzenbach, Eds., pp. 801-813, ASM Press, Washington DC, 2nd edition, 2002.

[20] M. E. Emetere, "Statistical examination of the aerosols loading over Mubi-Nigeria: the satellite observation analysis," Geographica Panonica, vol. 20, no. 2, pp. 62-69, 2016.

[21] M. E. Emetere, "Generation of atmospheric constants over some locations in West Africa: a theoretical aid for measuring instruments design," International Journal of Engineering Research in Africa, vol. 27, pp. 119-146, 2016.

[22] M. E. Emetere, "Investigations on aerosols transport over micro- and macro-scale settings of West Africa," Environmental Engineering Research, vol. 22, no. 1, pp. 75-86, 2016.

[23] M. E. Emetere and O. C. Olawole, "Environmental effect of corrosion on meteorological parameters over malabo," Procedia Manufacturing, vol. 35, pp. 854-860, 2019.

[24] A. K. Sudheer and R. Rengarajan, "Atmospheric mineral dust and trace metals over urban environment in Western India during winter," Aerosol and Air Quality Research, vol. 12, no. 5, pp. 923-933, 2012.

[25] D. G. Kaskaoutis, S. Kumar, D. Sharma et al., "Effects of crop residue burning on aerosol properties, plume characteristics, and long-range transport over northern India," Journal of Geophysical Research: Atmospheres, vol. 119, pp. 5424-5444, 2014.

[26] K. H. B. Shaeb, “Aerosol studies over Central India," in Hydrocarbon Pollution and its Effect on the EnvironmentIntechOpen.

[27] T. He, Study of atmospheric aerosol transport processes on local and regional scales, [Ph.D. thesis], University of Nova Gorica, 2013.

[28] M. Lv, D. Min, X. Li, Y. Yue, and X. Chen, "Mechanism of microbiologically influenced corrosion of X65 steel in seawater containing sulfate-reducing bacteria and iron-oxidizing bacteria," Journal of Materials Research and Technology, vol. 8, no. 5, pp. 4066-4078, 2019.

[29] N. De Leon-Rodriguez, T. L. Lathem, L. M. Rodriguez-R et al., "Microbiome of the upper troposphere: species composition and prevalence, effects of tropical storms, and atmospheric implications," Proceedings of the National Academy of Sciences, vol. 110, no. 7, pp. 2575-2580, 2013.

[30] D. J. Smith, H. J. Timonen, D. A. Jaffe et al., "Intercontinental dispersal of bacteria and archaea by transpacific winds," Applied and Environmental Microbiology, vol. 79, no. 4, pp. 1134-1139, 2013.

[31] J. Fröhlich-Nowoisky, C. J. Kampf, B. Weber et al., "Bioaerosols in the earth system: climate, health, and ecosystem interactions," Atmospheric Research, vol. 182, pp. 346-376, 2016. 
[32] I. Gandolfi, V. Bertolini, and R. Ambrosini, "Unravelling the bacterial diversity in the atmosphere," Applied Microbiology and Biotechnology, vol. 97, no. 11, pp. 4727-4736, 2013.

[33] V. R. Després, J. A. Huffman, S. M. Burrows et al., "Primary biological aerosol particles in the atmosphere: a review," Tellus $B$, vol. 64, pp. 1-53, 2012.

[34] J. A. Huffman, A. J. Prenni, P. J. DeMott et al., "High concentrations of biological aerosol particles and ice nuclei during and after rain," Atmospheric Chemistry and Physics, vol. 13, pp. 6151-6164, 2013.

[35] J. Mandal and H. Brandl, "Bioaerosols in indoor environment - a review with special reference to residential and occupational locations," The Open Environmental and Biological Monitoring Journal, vol. 4, pp. 83-96, 2011.

[36] C. J. Schumacher, C. Pöhlker, P. Aalto et al., "Seasonal cycles of fluorescent biological aerosol particles in boreal and semi-arid forests of Finland and Colorado," Atmospheric Chemistry and Physics, vol. 13, no. 23, pp. 11987-12001, 2013.

[37] A. M. Womack, P. E. Artaxo, F. Y. Ishida et al., "Characterization of active and total fungalcommunities in the atmosphere over the Amazon rainforest," Biogeosciences, vol. 12, no. 21, pp. 6337-6349, 2015.

[38] C. Jiayu, R. Qiaoqiao, C. Feilong et al., "Microbiology community structure in bioaerosols and the respiratory diseases," Journal of Environmental Science and Public Health, vol. 3, pp. 347-357, 2019.

[39] J. A. Sagona, S. L. Shalat, and Z. Wang, "Comparison of particulate matter exposure estimates in young children from personal sampling equipment and a robotic sampler," Journal of Exposure Science \& Environmental Epidemiology, vol. 27, pp. 299-305, 2016.

[40] J. Narenkumar, M. S. AlSalhi, A. A. Prakash et al., "Impact and role of bacterial communities on biocorrosion of metals used in the processing industry," Acs Omega, vol. 4, no. 25, pp. 21353-21360, 2019.

[41] A. Rajasekar, W. Xiao, M. Sethuraman, P. Parthipan, and P. Elumalai, "Airborne bacteria associated with corrosion of mild steel 1010 and aluminum alloy 1100," Environmental Science and Pollution Research, vol. 24, pp. 8120-8136, 2017.

[42] D. Fuente, I. Diaz, J. Simancas, B. Chico, and M. Morcillo, "Long-term atmospheric corrosion of mild steel," Corrosion Science, vol. 53, no. 2, pp. 604-617, 2011.

[43] R. Zhang, X. Ai, Y. Wan, Z. Liu, D. Zhang, and S. Feng, "Surface corrosion resistance in turning of titanium alloy," International Journal of Corrosion, vol. 2015, Article ID 823172, 8 pages, 2015.

[44] R. J. C. MacDonald and E. V. Gibbons, Atmospheric corrosion behaviour of stainless steels in eight Canadian atmospheres: summary of ten years' results, Internal Report (National Research Council of Canada. Division of Building Research), 1966.

[45] D. Wallinder, O. Wallinder, and C. Leygraf, "Influence of surface treatment of type 304L stainless steel on atmospheric corrosion resistance in urban and marine environments," Corrosion, vol. 59, no. 3, pp. 220-227, 2003.

[46] Y. Yazawa, K. Yoshioka, and F. Togashi, "Effects of Cr, Mo and $\mathrm{Cu}$ on the atmospheric corrosion resistance of ferritic stainless steels in a coastal environment," Kawasaki Steel Technical Report, 1994.
[47] E. Almanza, M. J. Pérez, N. A. Rodríguez, and L. E. Murr, "Corrosion resistance of Ti-6Al-4V and ASTM F75 alloys processed by electron beam melting," Journal of Materials Research and Technology, vol. 6, no. 3, pp. 251-257, 2017.

[48] S. H. Mameng, R. Pettersson, C. Leygraf, and L. Wegrelius, "Atmospheric corrosion resistance of stainless steel: results of a field exposure program in the middle-east," BHM Bergund Hüttenmännische Monatshefte, vol. 161, no. 1, pp. 3343, 2016.

[49] R. W. Schutz, Corrosion-of-titanium-and-titanium-alloys, Corrosion Materials Park Ohio USA, SM-International, 2005.

[50] J. Y. Xin, J. R. Cui, J. Z. Niu et al., "Production of methanol from methane by methanotrophic bacteria," Biocatalysis and Biotransformation, vol. 22, pp. 225-229, 2004.

[51] Z. Wang, M. Wang, J. Jiang et al., "Atmospheric corrosion analysis and rust evolution research of Q235 carbon steel at different exposure stages in Chengdu atmospheric environment of China," Scanning, vol. 2020, Article ID 9591516, 8 pages, 2020.

[52] S. Baozhuang, X. Zuo, X. Cheng, and X. Li, "The role of chromium content in the long-term atmospheric corrosion process," npj Materials Degradation, vol. 37, pp. 1-9, 2020.

[53] R. K. Sinnott, "Chemical Engineering Design," Coulson and Richardson Series, 6, 4th edition, 2006.

[54] F. Y. M. Wan, Mathematical models and their analysis, Harper and Row Publishers, New York, USA, 1989.

[55] J. C. Gibbings, Dimensional Analysis, Springer, 2011.

[56] M. O. G. Portella, K. F. Portella, P. A. M. Pereira et al., "Atmospheric corrosion rates of copper, galvanized steel, carbon steel and aluminum in the metropolitan region of salvador, BA, Northeast Brazil," Procedia Engineering, vol. 42, pp. 171-185, 2012.

[57] American Society for Testing and Materials, ASTM G 1-90: Preparing, Cleaning, and Evaluating Corrosion Test Specimens, p. 7, 1990.

[58] H. Wang, C. Yu, S. Wang, and J. Gao, "Electrochemical corrosion behavior and prediction of corrosion rate for low alloy steel after tempering treatment," International Journal of Electrochemical Science, vol. 10, pp. 1169-1185, 2015.

[59] S. D. Kapusta, B. F. M. Pots, and I. J. Rippon, The application of corrosion prediction models to the design and operation of pipelines, Nace International, 2004.

[60] R. Nyborg and A. Dugstad, Reliability and limitations of corrosion prediction tools for oil and gas pipeline, Eurocorr/2004 (Nice: CEFRACOR), 2004.

[61] T. N. Guma and J. A. Abu, "A field study of outdoor atmospheric corrosion rates of mild steel around Kaduna metropolis," SSRG International Journal of Mechanical Engineering, vol. 5, no. 11, pp. 7-21, 2018.

[62] I. B. Abaje, B. A. Sawa, E. O. Iguisi, and A. A. Ibrahim, "A quantitative approach to vulnerability assessment of rural communities to climate change in Kaduna state, Nigeria," Nigerian Geographical Journal, vol. 10, no. 2, pp. 180-195, 2015.

[63] S. H. Nimyel and M. M. Namadi, "Determination of selected air quality parameters in Zaria and its environs, Kaduna State, Nigeria," Journal of Applied Sciences and Environmental Management, vol. 23, no. 8, article 1505, 2019.

[64] M. Morcillo, D. de la Fuente, I. DiÃÅaz, and H. Cano, "Atmospheric corrosion of mild steel," Revista de Metalurgia, vol. 47, no. 5, pp. 426-444, 2011. 
[65] CorrosionDoctor, "Corrosion in India," 2019, https:// corrosion-doctors.org/AtmCorros/mapIndia.htm.

[66] H. T. Dinh, J. Kuever, M. Mußmann, A. W. Hassel, M. Stratmann, and F. Widdel, "Iron corrosion by novel anaerobic microorganisms," Nature, vol. 427, no. 6977, pp. 829-832, 2004.

[67] H. C. Vasconcelos, B. M. Fernández-Pérez, J. Morales et al., "Development of mathematical models to predict the atmospheric corrosion rate of carbon steel in fragmented subtropical environments," International Journal of Electrochemical Science, vol. 9, pp. 6514-6528, 2014.

[68] M. E. Emetere, E. E. Okoro, E. T. Akinlabi, and S. Sanni, "Effect of atmospheric aerosol on corrosion of metallic surfaces," Procedia Manufacturing, vol. 35, pp. 666-673, 2019.

[69] S. Huzni, I. Tanjung, and S. Fonna, "Atmospheric corrosion map of structural steel in industrial area: a preliminary investigation," IOP Conference Series: Materials Science and Engineering, vol. 602, article 012075, 2019.

[70] "International Organization for Standardization," December 2019, https://corrosion-doctors.org/Corrosion-Atmospheric/ Classification-schemes.htm. 